\title{
Macrobenthic assemblage structure and organismal stoichiometry control faunal processing of particulate organic carbon and nitrogen in oxygen minimum zone sediments
}

\author{
W. R. Hunter ${ }^{1}$, L. A. Levin ${ }^{2}$, H. Kitazato ${ }^{3}$, and U. Witte ${ }^{1}$ \\ ${ }^{1}$ Oceanlab, University of Aberdeen, Newburgh, Aberdeenshire, AB41 6AA, UK \\ ${ }^{2}$ Center for Marine Biodiversity and Conservation and Integrative Oceanography Division, Scripps Institute of Oceanography, \\ University of California San Diego, La Jolla, California, USA \\ ${ }^{3}$ Japan Agency for Marine-Earth Science and Technology, Natsushima 2-15, Yokosuka, Kanagawa 237-0061, Japan
}

Correspondence to: W. R. Hunter (r01wh8@ abdn.ac.uk)

Received: 11 October 2011 - Published in Biogeosciences Discuss.: 31 October 2011

Revised: 10 February 2012 - Accepted: 29 February 2012 - Published: 13 March 2012

\begin{abstract}
The Arabian Sea oxygen minimum zone (OMZ) impinges on the western Indian continental margin between 150 and $1500 \mathrm{~m}$, causing gradients in oxygen availability and sediment geochemistry at the sea floor. Oxygen availability and sediment geochemistry are important factors structuring macrofaunal assemblages in marine sediments. However, relationships between macrofaunal assemblage structure and sea-floor carbon and nitrogen cycling are poorly understood. We conducted in situ ${ }^{13} \mathrm{C}:{ }^{15} \mathrm{~N}$ tracer experiments in the OMZ core $\left(540 \mathrm{~m}\left[\mathrm{O}_{2}\right]=0.35 \mu \mathrm{moll}^{-1}\right)$ and lower OMZ boundary $\left(800-1100 \mathrm{~m},\left[\mathrm{O}_{2}\right]=2.2-15.0 \mu \mathrm{moll}^{-1}\right)$ to investigate how macrofaunal assemblage structure, affected by different oxygen levels, and C:N coupling influence the fate of particulate organic matter. No macrofauna were present in the OMZ core. Within the OMZ boundary, relatively high abundance and biomass resulted in the highest macrofaunal assimilation of particulate organic carbon (POC) and nitrogen (PON) at the lower oxygen $800 \mathrm{~m}$ stations $\left(\left[\mathrm{O}_{2}\right]=2.2-2.36 \mu \mathrm{moll}^{-1}\right)$. At these stations the numerically dominant cirratulid polychaetes exhibited greatest POC and PON uptake. By contrast, at the higher oxygen $1100 \mathrm{~m}$ station $\left(\left[\mathrm{O}_{2}\right]=15.0 \mu \mathrm{mol}^{-1}\right)$ macrofaunal $\mathrm{C}$ and $\mathrm{N}$ assimilation was lower, with POC assimilation dominated by one large solitary ascidian. Macrofaunal POC and PON assimilation were influenced by changes in oxygen availability, and significantly correlated to differences in macrofaunal assemblage structure between stations. However, macrofaunal feeding responses were ultimately characterised by preferential organic nitrogen assimilation, relative to their internal $\mathrm{C}: \mathrm{N}$ budgets.
\end{abstract}

\section{Introduction}

Episodic depositions of dead phytoplankton (phytodetritus) represent a major input of particulate organic matter (POM) to the deep-sea floor, stimulating the feeding and reproductive responses of the faunal and microbial assemblages that control sea-floor carbon cycling (reviewed by Smith et al., 2010). The bathyal continental margins (200-3000 m) account for a mere $7 \%$ of the global sea floor but recycle $\sim 30 \%$ of oceanic sedimentary POM (Middelburg et al., 1997). Oxygen minimum zones (OMZs) are stable bodies of poorly oxygenated water $\left(<22 \mu \mathrm{moll}^{-1}\right)$ persisting along the continental margins of the eastern Pacific Ocean, Arabian Sea and southwest Africa (Levin, 2003). OMZs are maintained by high primary productivity at the oceans surface and poor advective mixing of the water column, resulting in high organic matter flux and biological oxygen demand within the water column; and accumulation of organic matter in OMZimpacted sediments (Devol and Hartnett, 2001; Hartnett et al., 1998). OMZs currently impinge upon $\sim 6 \%$ of the continental margin sea floor (Helly and Levin, 2004) but are predicted to expand as consequences of anthropogenic climate change and ecosystem degradation (Bakun and Weeks, 2004; Stramma et al., 2008).

Metazoan macrofauna (size range: $250-1000 \mu \mathrm{m}$ ) are important contributors to ecosystem processes in deep sea sediments. Macrofauna contribute directly to OM recycling through ingestion, assimilation and respiration (e.g. Aberle and Witte, 2003; Witte et al., 2003a). Indirectly, macrofaunal subduction of POM provides an important route

Published by Copernicus Publications on behalf of the European Geosciences Union. 
for deposition of organic matter deeper into the sediment (e.g. Levin et al., 1997, 1999), whilst macrofaunal bioturbation enhances sediment oxygenation; stimulates aerobic metabolism by the sediment community (e.g. Kristensen and Holmer, 2001); and provides microhabitats for microbes and meiofauna (reviewed by Giblin et al., 1995). Macrofaunal also influence sediment microorganisms through predation and competition for resources (e.g. Aller, 1994; Wieltschnig et al., 2008; Hunter et al., 2012) . At OMZ-impacted continental margins the macrofaunal assemblages are influenced by depth-dependent changes in ambient oxygen availability and differences in organic matter $(\mathrm{OM})$ availability within the sediments (e.g. Levin and Gage, 1998). Macrofauna are often absent in the OMZ core, where oxygen levels are lowest; whilst high abundance, low diversity assemblages are typical at the OMZ boundaries. By contrast, seafloor outside the OMZ's influence are characterised by low-density, macrofaunal assemblages (Levin et al., 1991, 2000, 2009; Ingole et al., 2010). High macrofaunal abundances in the OMZ boundaries are driven primarily by hypoxia-tolerant polychaete genera, such as the ampheretid Linopherus spp., the spionid Prionospio spp. or the cirratulid Monticellina spp. (e.g. Levin and Edesa, 1997; Levin et al., 2000; 2009; Ingole et al., 2010). Macrofaunal diversity is positively correlated to oxygen availability, increasing concomitantly with decreases in macrofauna abundance across the OMZ boundary (e.g. Levin et al., 2000, 2009).

Quantifying the role of the fauna within ecosystem processes is important in order to develop accurate models of sea floor carbon and nitrogen cycling. Stable-isotope labelling techniques allow pathways and rates of $\mathrm{OM}$ processing to be traced over short time periods. So far, these methods have primarily been used to trace the pathways and processing of organic carbon in deep-sea sediments, using ${ }^{13} \mathrm{C}$ labelled phytodetritus. Following deposition of labelled phytodetritus, macrofauna rapidly ingest the ${ }^{13} \mathrm{C}$ label and are responsible for its subduction below the sediment surface (e.g. Levin et al., 1997; Aberle and Witte, 2003; Witte et al., 2003a). Macrofauna play an important role in the initial community response, both directly consuming OM and mediating its availability to other organismal groups (e.g. Witte et al., 2003b; Moodley et al., 2005). At the OMZ-impacted Pakistan margin, macrofauna significantly influenced the fate of OM within the sediments. The polychaete Linopherus spp., which occurred in high densities, consumed between $45-80 \%$ of the isotopically-labelled OM deposited between 850 and $1800 \mathrm{~m}$, in the OMZ lower boundary (Woulds et al., 2007). However, the relationship between macrofaunal assemblage structure and OM processing remain largely unexplored.

Organic nitrogen availability limits secondary production in marine sediments and may limit carbon cycling at the seabed (Vitousek and Howarth, 1991). Dual-labelling $\left({ }^{13} \mathrm{C}:{ }^{15} \mathrm{~N}\right)$ studies simultaneously traced the utilisation of organic $\mathrm{C} \& \mathrm{~N}$ in intertidal (Rossi, 2007) and shallow subtidal sediments (Evrard et al., 2010), demonstrating that faunal and microbial $\mathrm{N}$ demand are important drivers of OM recycling. However, $\mathrm{C} \& \mathrm{~N}$ are physiologically decoupled by individual organisms, which use C-rich (e.g. carbohydrates; lipids) and N-rich (e.g. amino acids) organic compounds differently: for respiration and energy storage; and growth respectively (e.g. Frost et al., 2002; Persson et al., 2010). Faunal processing of particulate organic carbon (POC) and nitrogen (PON) are determined by the internal budgets of individual organisms, controlled by changes in ontogeny and physiology (reviewed in Sterner and Elser, 2002). Therefore, in order to understand macrofaunal contributions to benthic carbon cycling, we must investigate the relationships between macrofaunal carbon and nitrogen processing.

The aim of the present study is to exploit oxygen-driven gradients in macrofaunal assemblage composition across the lower boundary of an OMZ to explore relationships between macrofaunal assemblage structure and short term processing of phytodetritus-derived carbon and nitrogen. Pulses of ${ }^{13} \mathrm{C}:{ }^{15} \mathrm{~N}$ labelled diatoms simulated a phytodetritus deposition event, and assimilation of phytodetrital carbon and nitrogen by the macrofauna were traced over four and seven days. We hypothesise that oxygen limitation will modify macrofaunal assemblage composition, influencing faunal POC and $\mathrm{PON}$ processing. Variations in organismal C:N ratios reflect differences in POC and PON demand within the fauna. Therefore, we predict that differential POC and PON assimilation will reflect the organismal stoichiometric budgets within each macrofaunal assemblage.

\subsection{Materials \& methods}

\subsubsection{Study area}

The Arabian Sea OMZ impinges upon the western Indian continental margin between 150 and $1500 \mathrm{~m}$. Ambient oxygen levels at the sea floor fall as low as $0.35 \mu \mathrm{mol} 1^{-1}$ at $540 \mathrm{~m}$, increasing to $2.2-2.36 \mu \mathrm{moll}^{-1}$ at $800 \mathrm{~m}$ and $15.00 \mu \mathrm{moll}^{-1}$ at $1100 \mathrm{~m}$ (Hunter et al., 2011). Stableisotope labelling experiments were conducted at four stations on the Indian continental margin, (Fig. 1; Table 1). These span differing oxygen regimes within the OMZ core $(540 \mathrm{~m})$ and lower OMZ boundary (800-1100 m). All stations were visited during the 2008 post-monsoon period (SeptemberNovember) as part of R/V Yokosuka cruise YK08-11.

\subsubsection{Experimental design}

Prior to YK08-11, an axenic clone of Thallassiosira weissflogii (CCMP, Bigelow marine Laboratories) was cultured in artificial seawater and $L 1$ culture medium enriched with $99 \%{ }^{13} \mathrm{C}$-bicarbonate $\left(\mathrm{NaH}^{13} \mathrm{CO}_{3}\right.$, Cambridge Isotope Laboratories) and $50 \%{ }^{15} \mathrm{~N}$-sodium nitrate $\left(\mathrm{Na}^{15} \mathrm{NO}_{3}\right.$, Cambridge Isotope Laboratories). Algae were cultured at $16^{\circ} \mathrm{C}$ (light: dark $=16: 8$; salinity $=35$; duration $=28$ 
Table 1. Environmental conditions. Oxygen, Temperature and Salinity data are as reported in Hunter et al., (2011). Porosity values represent the means $( \pm \mathrm{SD})$, between 00 and $05 \mathrm{~cm}$ sediment depth, of three background sediment cores at each station. Sediment Organic matter and Unprocessed Algal material data are presented as the mean values $( \pm \mathrm{SD})$ for the upper $5 \mathrm{~cm}$ sediment, within each spreader experiment.

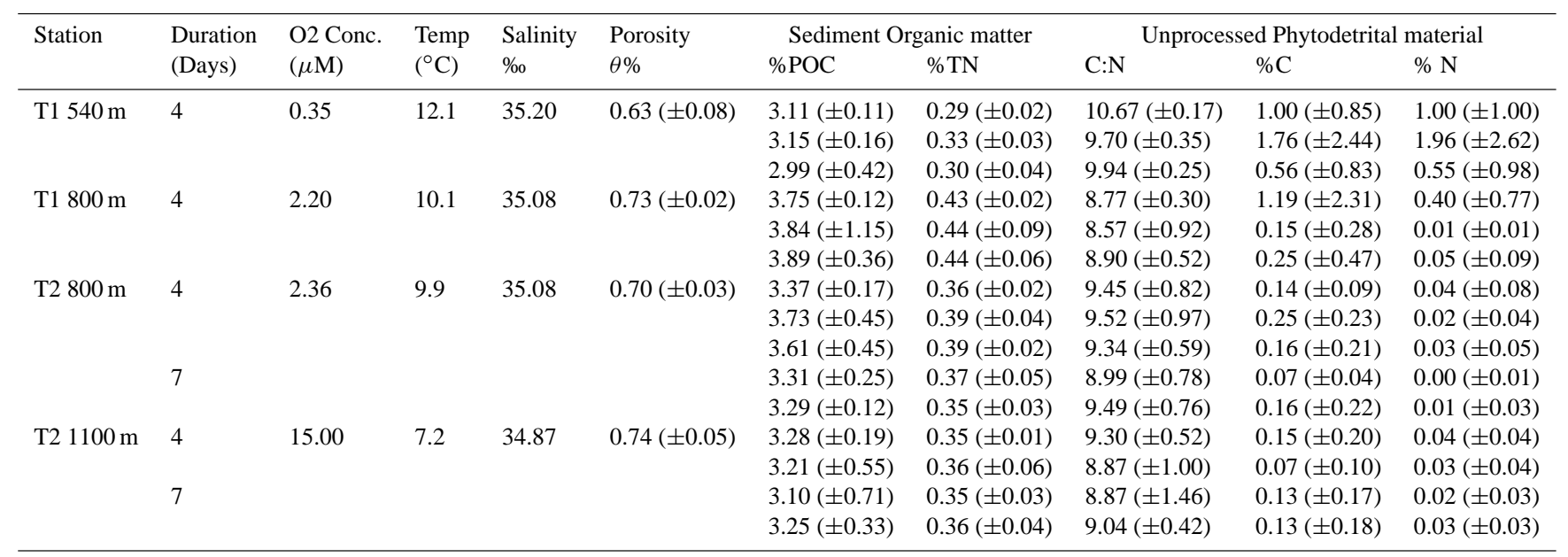

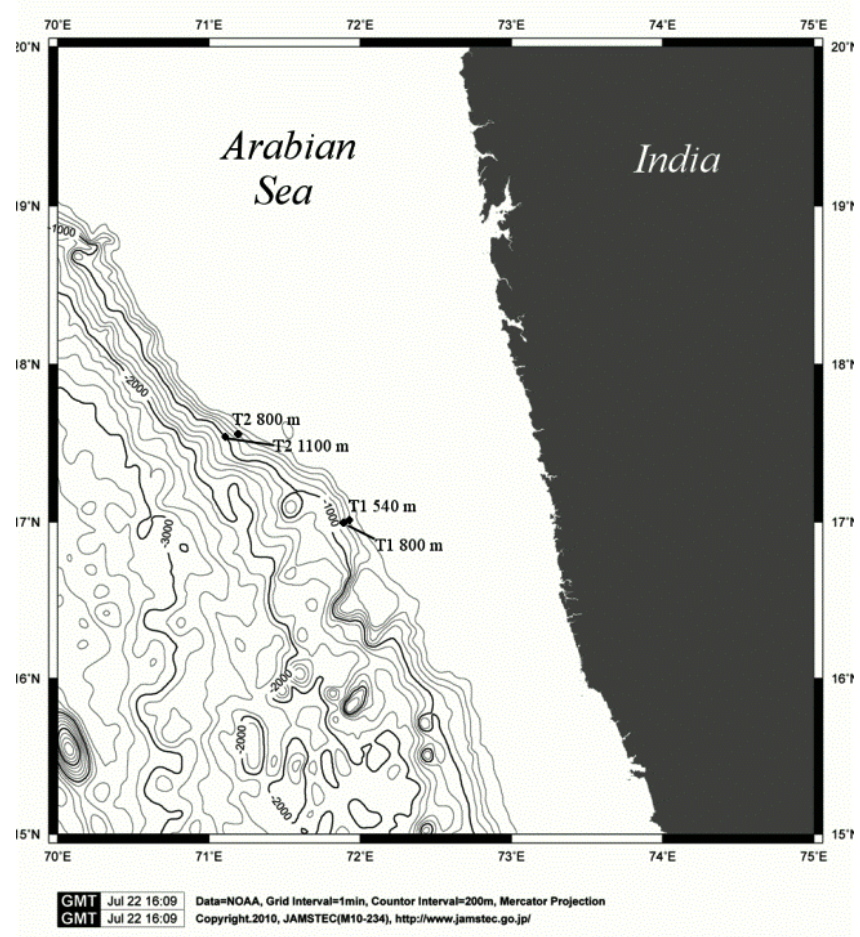

Fig. 1. Map of the study area indicating the location of experimental stations.

days), harvested by centrifugation $(500 \mathrm{G} ; 30 \mathrm{~min})$, sonicated $(2000 \mathrm{~Hz} ; 5 \mathrm{mins})$ and rinsed three times in ultrapure water (milli-Q) to remove inorganic salts and dissolved organic carbon (DOC). Harvested algae were lyophilised $\left(-60^{\circ} \mathrm{C}\right.$;
$-0.0001 \mathrm{mbar} ; 24 \mathrm{hrs}$ ) to produce phytodetritus containing 27.75 atom $\%{ }^{13} \mathrm{C} ; 33.70$ atom $\%{ }^{15} \mathrm{~N}$, with a $\mathrm{C}: \mathrm{N}$ mass ratio of 4.06 .

Experiments were conducted using Oceanlab spreader systems. These are in situ meso-cosms consisting of a transparent polycarbonate tube (diameter: $25 \mathrm{~cm}$, length: $30 \mathrm{~cm}$ ) and acetal plastic lid. The lid of each spreader contains an injector unit that releases a known dose of isotopically-labelled phytodetritus onto the enclosed sediment surface $\left(0.049 \mathrm{~m}^{2}\right)$. Spreaders were deployed by the submersible Shinkai 6500, which gently pushed each tube into the sediment. A marinegrade plywood collar, approx. $10 \mathrm{~cm}$ above the base of the spreader tube, prevented it being pushed too far into the sediment and provided additional stability. Labelled phytodetritus was released by pushing an elastically-tensioned plunger, rupturing the membrane of the injector unit. The spreader lid was left in place for a minimum of two hours, to allow the phytodetritus to settle, and then removed to mitigate against experimentally-induced hypoxia (Riedel et al., 2008). The polycarbonate tube was left in situ for the duration of the experiment. At the end of each experiment the sediment enclosed within a spreader was sampled using push cores and the polycarbonate tube recovered.

Three spreaders were deployed at each station for four day incubations, using the submersible Shinkai 6500. Three replicate spreaders were also deployed for seven day incubations at stations T2 $800 \mathrm{~m}$ and T2 $1100 \mathrm{~m}$ (Table 1). Spreaders were positioned approximately $2 \mathrm{~m}$ apart on areas of undisturbed sediment and placed into the sediment with minimal resuspension. Experiments commenced with the deposition of a fixed dose of ${ }^{13} \mathrm{C}:{ }^{15} \mathrm{~N}$ labelled T. Weissflogii slurry (650 $\mathrm{mg} \mathrm{C} \mathrm{m}^{-2} ; 160 \mathrm{mg} \mathrm{N} \mathrm{m}^{-2}$ ). Spreaders were left in situ 
for four or seven days, after which each was sampled with three push cores. Cores were horizontally sectioned in $1 \mathrm{~cm}$ intervals to $3 \mathrm{~cm}$ depth, then in $2 \mathrm{~cm}$ intervals to $7 \mathrm{~cm}$ depth, and a $3 \mathrm{~cm}$ fraction between 7 and $10 \mathrm{~cm}$. One core from each spreader was allocated for macrofaunal extraction, one core was allocated for extraction of foraminifera and meiofaunal, and one core was used for microbiological and geochemical analysis. Loss of cores during sampling resulted in the recovery of only two replicate 4 day incubations at station T2 $1100 \mathrm{~m}$ and two replicates from each 7 day incubation (T2 $800 \mathrm{~m}$ and T2 $1100 \mathrm{~m}$ ). 25 additional background cores were taken to provide natural stable isotope signatures of the fauna (13 between 800 and $1100 \mathrm{~m}$ ) and sediments ( 3 at each station).

\subsubsection{Sample processing and data treatment}

The upper $5 \mathrm{~cm}$ of sediment from each macrofauna core was wet-sieved through a $250 \mu \mathrm{m}$ mesh, using filtered sea water. Sieve residues were picked for macrofauna (under $x 12$ and $x 20$ magnification) and transferred to $4 \%$ buffered formaldehyde solution. Macrofauna were sorted to family (and genus where possible), rinsed in ultrapure water and dried to constant weight at $60^{\circ} \mathrm{C}$. All fauna were decarbonated by addition of 1-2 drops of analytical grade $6 \mathrm{moll}^{-1}$ hydrochloric acid $\left(\mathrm{HCl}_{\mathrm{aq}}\right)$. Sediment samples were centrifuged to extract pore water, homogenized and frozen immediately at $-80^{\circ} \mathrm{C}$. Post-cruise, frozen sediments were sub-sampled and $3 \mathrm{~g}$ aliquots lyophilised $\left(-60^{\circ} \mathrm{C} ;-0.0001 \mathrm{mbar} ; 24 \mathrm{hrs}\right)$. Lyophilised sediments were decarbonated by addition of excess $1 \mathrm{moll}^{-1} \mathrm{HCl}_{\mathrm{aq}}$, incubated for $24 \mathrm{hrs}$ at $30^{\circ} \mathrm{C}$ in an acidfumed environment and dried to constant weight at $60^{\circ} \mathrm{C}$. Mean sediment porosity was estimated from the change in mass and volume during lyophilisation (following Hunter et al., 2011).

Organic carbon and nitrogen concentrations and the isotopic ratios $\left({ }^{13} \mathrm{C} /{ }^{12} \mathrm{C}\right.$ and $\left.{ }^{15} \mathrm{~N} /{ }^{14} \mathrm{~N}\right)$ of fauna and sediment were determined using a PDZ Europa ANCA-GSL elemental analyser linked to a PDZ Europa 20-20 IRMS (Sercon Ltd, Cheshire UK). Samples were combusted at $1000^{\circ} \mathrm{C}$ with helium $(\mathrm{He})$ used as the carrier gas. Fauna were analysed, with the IRMS and internal standards adapted for low carbon samples. Isotope ratio data, expressed in $\delta$ units (\%o), was used to calculate the atom $\%{ }^{13} \mathrm{C}$ and ${ }^{15} \mathrm{~N}$ by

$a t \% X_{\text {sample }}=\left(\frac{\left(X_{\text {sample }} / 1000\right) \times R_{\text {standard }} \times 100+1}{\left(X_{\text {sample }} / 1000\right) \times R_{\text {standard }}+1}\right)$

where at $\% \mathrm{X}_{\text {sample }}$ is the ${ }^{13} \mathrm{C}$ or ${ }^{15} \mathrm{~N}$ content of the sample (in atom \%) $X_{\text {sample }}$ is the isotopic ratio $\left({ }^{13} \mathrm{C}\right.$ or $\left.{ }^{15} \mathrm{~N}\right)$ of the sample (in $\delta$ units) and $\mathrm{R}_{\text {standard }}$ is an international reference material: Vienna PeeDee Belemnite for $\mathrm{C}\left(R_{\mathrm{VPDB}}=0.0112372\right)$; atmospheric nitrogen for $\mathrm{N}$ $\left(R_{\mathrm{atmN}}=0.0036765\right)$. Faunal ${ }^{13} \mathrm{C}$ values were corrected for formaldehyde preservation effects by adding $1 \%$ to each $\delta^{13} \mathrm{C}$-value (following Sweetman and Witte 2008a, b; Gontikaki et al., 2011). Excess ${ }^{13} \mathrm{C}$ and ${ }^{15} \mathrm{~N}$ concentrations in each sample were calculated following Middelburg et al., (2000) as

$E=\left(\frac{\left(a t \% X_{\text {sample }}-a t \% X_{\text {background }}\right)}{100}\right)$

where $E$ is the excess isotopic label, at $\% \mathrm{X}_{\text {sample }}$ is the atom $\%{ }^{13} \mathrm{C}$ or ${ }^{15} \mathrm{~N}$ of the sample, and at $\% \mathrm{X}_{\text {background }}$ is the atom $\%{ }^{13} \mathrm{C}$ or ${ }^{15} \mathrm{~N}$ of the background material. Background ${ }^{13} \mathrm{C}$ and ${ }^{15} \mathrm{~N}$ values were determined from the natural isotopic signatures of macrofauna sampled at the Indian margin. Incorporation of the ${ }^{13} \mathrm{C}$ and ${ }^{15} \mathrm{~N}$ was calculated as the product of isotopic label excess and the faunal carbon or nitrogen content. Assimilation of phytodetrital carbon (phyto C) and nitrogen $\left({ }_{\text {phyto }} \mathrm{N}\right)$ was calculated by

$I_{\text {phyto }}=\frac{I_{\text {iso }}}{\left(a t \% X_{\text {phyto }} / 100\right)}$

where $I_{\text {phyto }}$ is the concentration of phyto $\mathrm{C}$ or phyto $\mathrm{N}, I_{\text {iso }}$ is the amount of ${ }^{13} \mathrm{C}$ or ${ }^{15} \mathrm{~N}$ incorporated, and at $\% \mathrm{X}_{\text {phyto }}$ is the isotopic content $\left({ }^{13} \mathrm{C}\right.$ or $\left.{ }^{15} \mathrm{~N}\right)$ of the phytodetrital substrate, in atom \%. Sediment $\mathrm{C}$ and $\mathrm{N}$ concentrations, and isotopic data where determined as described for the fauna, against the natural isotopic signatures of background sediment samples. Sediment carbon and nitrogen content were used to calculate the molar $\mathrm{C}: \mathrm{N}$ ratio, as a proxy for sediment organic matter quality (Hedges and Keil 1995) and the percentage of phyto $\mathrm{C}$ and ${ }_{\text {phyto }} \mathrm{N}$ recovered in the sediment samples estimated for each experiment.

\subsubsection{Statistical analysis}

Environmental data for each station (Table 1) shows that alongside depth-dependent oxygen gradients, localised variations in sediment organic carbon and nitrogen content occur both within and between experimental stations. A scatterplot matrix (Fig. A1) displays the relationships between environmental variables and quantifies correlations using Spearman's rank correlation co-efficient. This matrix shows strong correlations between oxygen availability and most of the environmental variables (Temperature, salinity, POC, PON $\mathrm{A} \operatorname{lgC}, \mathrm{A} \lg \mathrm{N})$. Weak correlations were observed between oxygen availability and both sediment porosity and sediment $\mathrm{C}: \mathrm{N}$ ratios, but these variables were co-linear. Only ambient oxygen availability and sediment $\mathrm{C}: \mathrm{N}$ ratio, were used as descriptors of each station during analysis.

Macrofaunal assemblage structure ( $\mathrm{C} \& \mathrm{~N}$ biomass) and macrofaunal assimilation of phyto $\mathrm{C}$ and ${ }_{\text {phyto }} \mathrm{N}$ where modelled as responses to changes in sediment $\mathrm{C}: \mathrm{N}$ ratios and oxygen availability, between stations by Constrained Analysis of Principle Components (CAPSCALE) (Anderson and Willis, 2003). T1 $540 \mathrm{~m}$ was excluded from analyses because macrofauna were absent at this station. The solitary 
ascidian at T2 $1100 \mathrm{~m}$ was excluded from these analyses as an extreme outlier. Biomass $\mathrm{C}$ and biomass $\mathrm{N}$ were transformed by $\sqrt{ }(x+0.01)$ to reduce the influence of highly abundant taxa. ${ }_{\text {phyto }} \mathrm{C}$ and ${ }_{\text {phyto }} \mathrm{N}$ assimilation data were transformed by $\sqrt[3]{ } \sqrt{(x+0.01)}$, to control for the effects of differences in incubation time at T2 $800 \mathrm{~m}$ and T2 $1100 \mathrm{~m}$ and reduce the influence of highly abundant taxa. Ordination models were constructed from Bray-Curtis dissimilarity matrices, with the multivariate normality of each matrix tested using beta-dispersion tests (1000 permutations, $p<0.05$ ) (Anderson, 2006). Model selection was carried out by minimizing the Aikaike Information Criterion (Bedrick and Tsai, 1994). Significance of the final ordination models were tested by permutational analysis of variance (1000 permutations, $p<0.05$ ) (Anderson and Willis, 2003). Multivariate correlations between changes in phyto $\mathrm{C}$ and ${ }_{\text {phyto }} \mathrm{N}$ assimilation to changes in macrofaunal assemblage structure (biomass $\mathrm{C}$ and biomass $\mathrm{N}$ ) were tested by Procrustes rotational tests (PROTEST) between final ordination models. This method compares data matrices using a rotational-fit algorithm to minimise their sum-of square residuals and calculate a goodness-of-fit statistic $\left(\mathrm{m}^{2}\right)$. The significance of the $\mathrm{m}^{2}$ statistic was tested using a randomisation test $(1000$ permutations; $p<0.05)$ (Jackson, 1995). All analyses were carried out in $R 2.9 .2$ (R Development Core Team 2009) using VEGAN (Oksanen et al., 2009) and MASS (Venables and Ripley, 2002) packages.

\subsection{Results}

\subsubsection{Macrofaunal assemblage}

Description of the macrofauna at each station is based upon both four and seven day experiments, with each spreader treated as a replicate. Sample sizes were $n=3$ at stations $\mathrm{T} 1540 \mathrm{~m}$ and $\mathrm{T} 1800 \mathrm{~m}, n=5$ at T2 $800 \mathrm{~m}$ and $n=4$ at T2 $1100 \mathrm{~m}$ metazoan macrofauna were absent at T1 $540 \mathrm{~m}$, where oxygen levels were $\sim 0.36 \mu \mathrm{moll}^{-1}$. Between 800 and $1100 \mathrm{~m}$, total abundance, biomass $\mathrm{C}$ and biomass $\mathrm{N}$ were higher at T1 $800 \mathrm{~m}$ and $\mathrm{T} 2800 \mathrm{~m}$, compared with T2 $1100 \mathrm{~m}$ (Fig. 2). In the present study the definition of macrofauna included large nematodes $(>250 \mu \mathrm{m})$, which contributed $\sim 30 \%$ of macrofaunal abundance at station T2 $800 \mathrm{~m}$, and $\sim 60 \%$ at T2 $1100 \mathrm{~m}$. Nematodes contributed little $\mathrm{C}$ or $\mathrm{N}$ biomass (Fig. 3). The polychaetes were the dominant macrofaunal taxa, by biomass. However, at T2 $1100 \mathrm{~m}$ the presence of s single large ascidian in one spreader contributed $\sim 45 \%$ of $\mathrm{C}$ biomass and $\sim 20 \%$ of $\mathrm{N}$ biomass.

Cirratulids and sabellids were the most abundant polychaete families at T1 $800 \mathrm{~m}$ and oweniids and cirratulids were abundant at T2 $800 \mathrm{~m}$ and T2 $1100 \mathrm{~m}$. Cirratulids and oweniids contributed most to polychaete $\mathrm{C} \& \mathrm{~N}$ biomass. The cirratulids were characterised by three genera: Cirratulus spp.; Tharyx spp.; and the mud-ball forming Monticellina spp. (Levin and Edesa 1997), and the oweniids represented
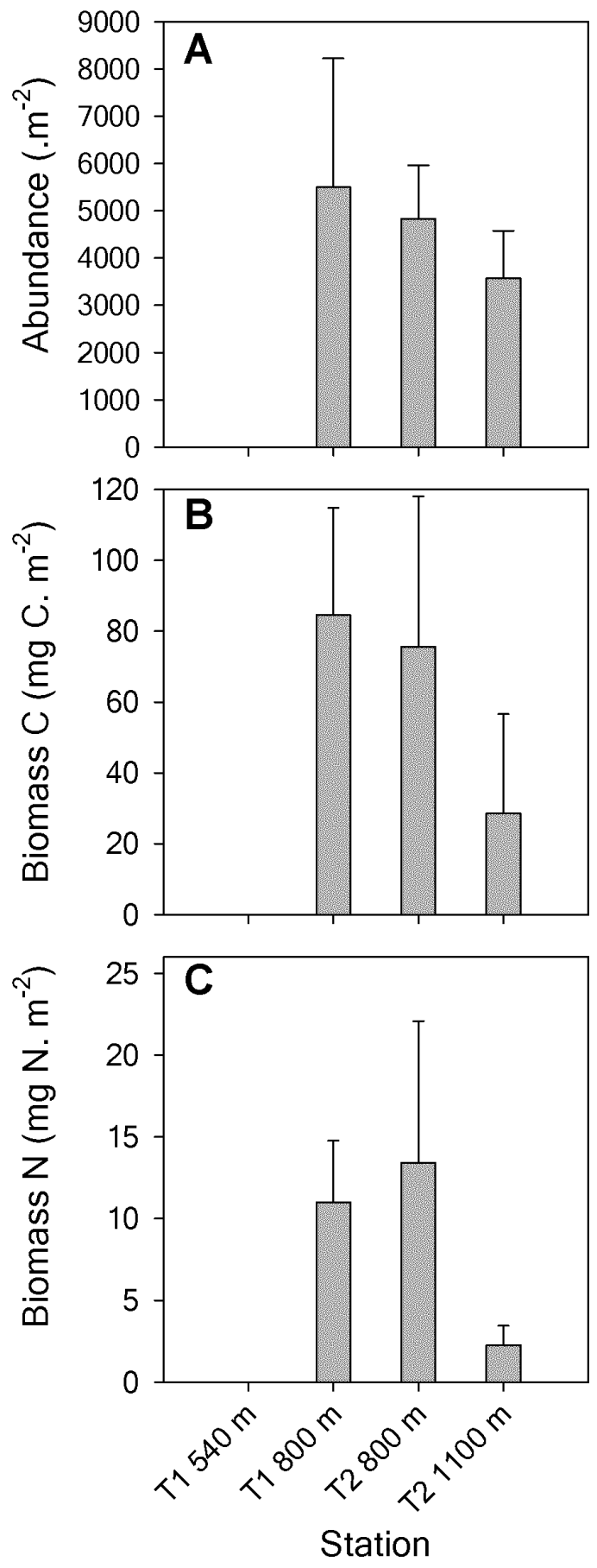

Fig. 2. Mean ( \pm standard deviation) macrofaunal (A) abundance, (B) biomass $\mathrm{C}$ and (C) biomass $\mathrm{N}$ at the four experimental stations.

by the genus Owenia spp. According to Fauchald and Jumars' (1979) polychaete feeding group classifications, stations T1 $800 \mathrm{~m}, \mathrm{~T} 2800 \mathrm{~m}$ and T2 $1100 \mathrm{~m}$ were dominated by surface deposit feeding polychaetes, with sub-surface deposit feeding families playing only a minor role. 

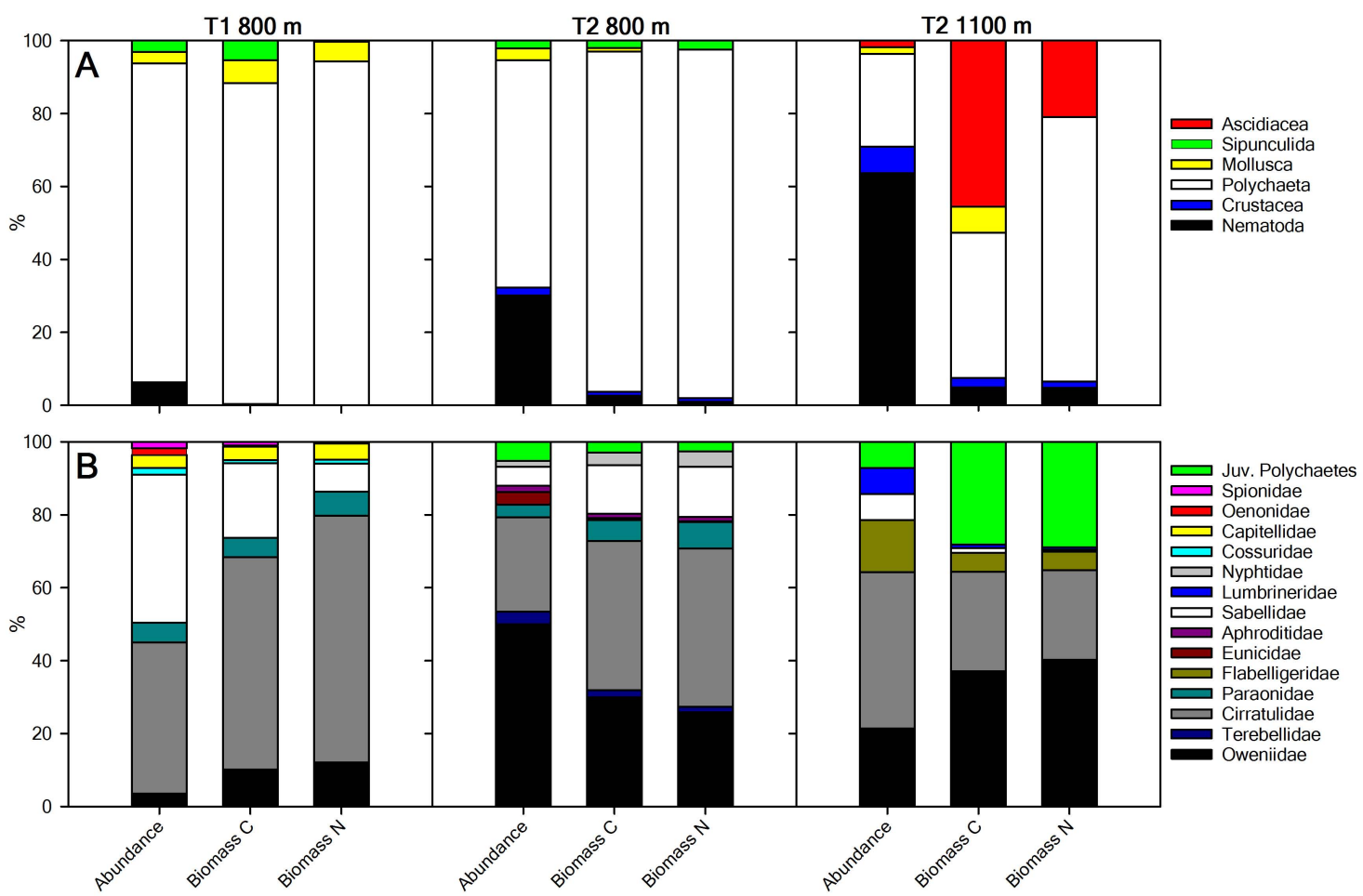

Fig. 3. Relative abundance, biomass $\mathrm{C}$ and biomass $\mathrm{N}$ of (A) the major macrofaunal taxa and (B) the polychaetes families at stations $\mathrm{T} 1$ $800 \mathrm{~m}, \mathrm{~T} 2800 \mathrm{~m}$ and T2 $1100 \mathrm{~m}$.

Natural abundance stable isotope signatures of the macrofauna are summarised in Fig. 4. The data exhibits considerably variation across all taxa. A harpactacoid copepod exhibited the most depleted $\delta^{13} \mathrm{C}$ signature $(-26 \%$ ) and an ophiuroid displayed the heaviest $\delta^{13} \mathrm{C}$ signature $(-11 \%$ ). $\delta^{15} \mathrm{~N}$ signatures typically ranged from 2 to $12 \%$. However, harpactacoid copepods, nyphtid polychaetes and bivalves all exhibited depleted $\delta^{15} \mathrm{~N}(<2 \%)$. Heavier $\delta^{15} \mathrm{~N}$ signatures $(>12 \%$ ) were observed in the turbellaria, as well as phoxocephalid crustacea and goniadid polychaetes. The natural isotopic signatures provide background data for the quantification of the ${ }^{13} \mathrm{C}$ and ${ }^{15} \mathrm{~N}$ enrichments of macrofauna in each spreader experiment.

\subsubsection{Macrofaunal uptake of phytodetrital $\mathrm{C}$ and $\mathrm{N}$}

Between 800 and $1100 \mathrm{~m}$, mean phyto $\mathrm{C}$ and phyto $\mathrm{N}$ processed by the metazoan macrofauna ranged from 5540.46 $( \pm 2482.74)$ to $1511.66( \pm 1862.28) \mu \mathrm{g} \mathrm{C} \mathrm{m}^{-2}$ and 355.50 $( \pm 334.82)$ to $21.96( \pm 20.04) \mu \mathrm{g} \mathrm{N} \mathrm{m}^{-2}$, after 4 days, and from $2150.56( \pm 1463.19)$ to $373.79( \pm 414.89) \mu \mathrm{g} \mathrm{C} \mathrm{m}^{-2}$ and $97.41( \pm 84.42)$ to $31.64( \pm 5.44) \mu \mathrm{g} \mathrm{N} \mathrm{m}^{-2}$, after 7 days. Between 4 and 7 days decreases in both phyto $\mathrm{C}$ and ${ }_{\text {phyto }} \mathrm{N}$ assimilation were observed at T2 800 and T2 $1100 \mathrm{~m}$. Assimilation of ${ }_{\text {phyto }} \mathrm{C}$ and ${ }_{\text {phyto }} \mathrm{N}$ was dominated by the cirratulids at both $800 \mathrm{~m}$ stations (Fig. 5). However, at T2 $800 \mathrm{~m}$, there is a shift in phyto $\mathrm{C}$ and ${ }_{\text {phyto }} \mathrm{N}$ assimilation between four and seven days from the cirratulids to other taxonomic groups. At T2 $1100 \mathrm{~m}$, differences in ${ }_{\text {phyto }} \mathrm{C}$ and ${ }_{\text {phyto }} \mathrm{N}$ assimilation were generally small between taxa. However, the solitary ascidian accounted for $\sim 76 \%$ of the faunal biomass and $\sim$ $75 \%$ of phyto $\mathrm{C}$ assimilation in one of the four day experiments at this station.

Biomass-specific phyto $\mathrm{C}$ and phyto $\mathrm{N}$ assimilation was relatively constant between macrofaunal taxa (Fig. 6). During the 4-day incubations, cirratulid polychaetes exhibited higher biomass specific assimilation at both $\mathrm{T} 1800 \mathrm{~m}$ and T2 $800 \mathrm{~m}$. However, greatest biomass-specific assimilation of both phyto $\mathrm{C}$ and phyto $\mathrm{N}$ were observed in a eunicid polychaete at T2 $800 \mathrm{~m}$. Likewise, at T2 $1100 \mathrm{~m}$, relatively high biomass specific assimilation of ${ }_{\text {phyto }} \mathrm{C}$ and ${ }_{\text {phyto }} \mathrm{N}$ were observed in a solitary flabelligerid polychaete. Fewer macrofauna were recovered from the 7-day experiments and biomass-specific phyto $\mathrm{C}$ and phyto $\mathrm{N}$ assimilation exhibited no taxon-specific changes between four and seven days.

\subsubsection{Multivariate ordination models}

CAPSCALE ordination models tested the significance of environmental changes upon macrofaunal assemblage structure and phyto $\mathrm{C}$ and ${ }_{\text {phyto }} \mathrm{N}$ assimilation, between stations (Fig. 7). The influence of sediment C:N ratios upon assemblage structure (biomass $\mathrm{C}$ and biomass $\mathrm{N}$ ) and feeding responses ( ${ }_{\text {phyto }} \mathrm{C}$ and ${ }_{\text {phyto }} \mathrm{N}$ assimilation) could not be isolated 

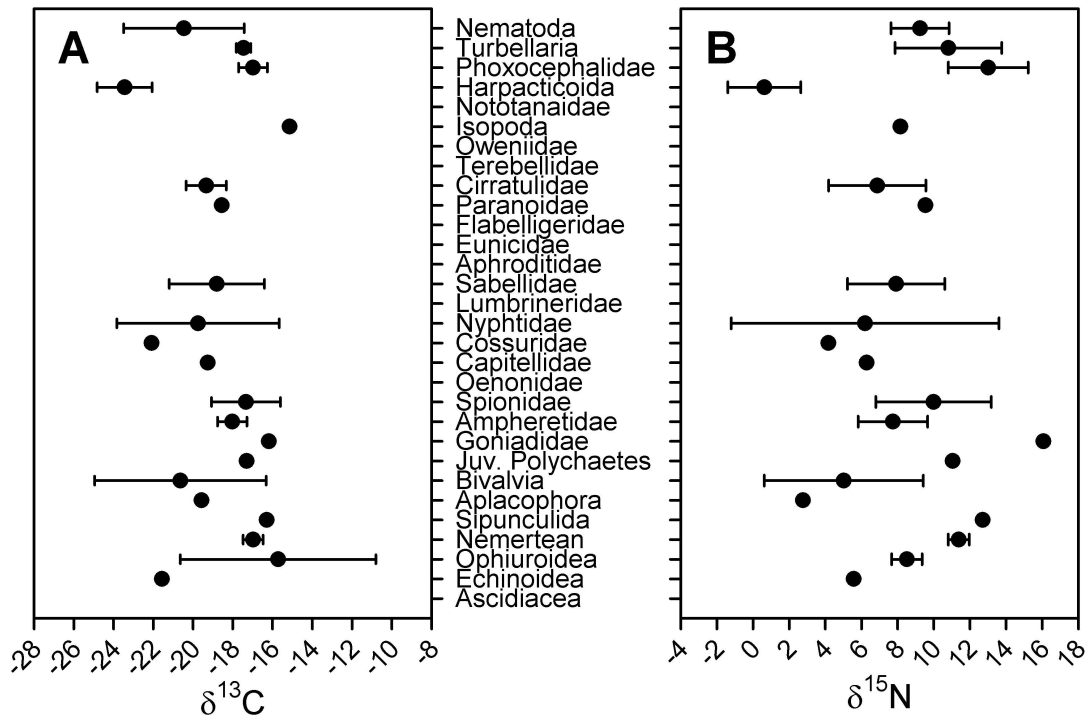

Fig. 4. Natural Stable-Isotopic signatures of macrofauna at the Indian continental margin. Data are means ( \pm standard deviations) from a series of 13 push cores taken between 800 and 1000 m, by Shinkai 6500 during YK08-11.
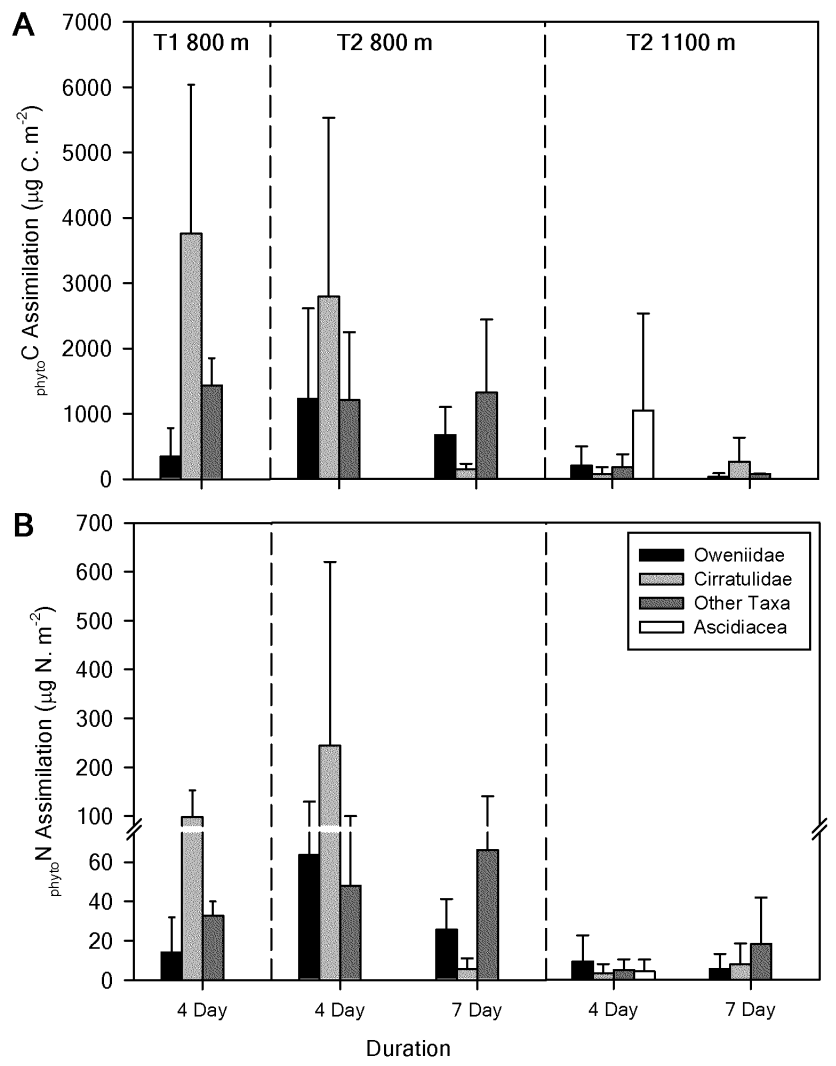

Fig. 5. Mean assimilation ( \pm standard deviation) of (A) phyto $\mathrm{C}$ and (B) phyto $^{\mathrm{N}}$ by the main macrofaunal taxa, over four and seven day incubation periods. from stochastic variations in the data and were excluded during model selection (Supplement data). CAPSCALE ordinations demonstrated significant relationships between ambient oxygen availability and macrofaunal assemblage structure (Fig. 7a, b). In addition, spatial variability within the ordination models indicates unconstrained heterogeneity in macrofaunal assemblage structure at all three stations. CAPSCALE ordinations showed that changes in oxygen availability to have significant effects upon macrofauna phyto $\mathrm{C} \&$ phyto $\mathrm{N}$ assimilation (Fig. 7c, d). Unconstrained spatial variability was again a feature of the ordinations, suggesting that ${ }_{\text {phyto }} \mathrm{C}$ and phyto $\mathrm{N}$ assimilation by the macrofaunal assemblage is influenced by assemblage structure. Procrustes rotational analysis confirms this by demonstrating significant correlations between macrofaunal assemblage structure (biomass $\mathrm{C}$ and biomass $\mathrm{N})$ and both phyto $\mathrm{C}$ assimilation $\left(\mathrm{m}^{2}=0.896\right.$; $p<0.001)$ and ${ }_{\text {phyto }} \mathrm{N}$ assimilation $\left(\mathrm{m}^{2}=0.989 ; p<0.001\right)$.

\subsubsection{Relationships between $\mathrm{C} \& \mathrm{~N}$ uptake}

Relationships between macrofauna phyto $\mathrm{C}$ and phyto $\mathrm{N}$ assimilation were explored by calculation of $\mathrm{C}: \mathrm{N}$ ratios for the somatic tissues of macrofaunal specimens, their total phyto $\mathrm{C}$ and ${ }_{\text {phyto }} \mathrm{N}$ assimilation and biomass specific assimilation of ${ }_{\text {phyto }} \mathrm{C}$ and ${ }_{\text {phyto }} \mathrm{N}$ at each station (Fig. 8). Somatic C:N ratios of the macrofauna ranged from 5 to 20 , with outliers between 30 and 40 observed in the nematodes; cirratulid and sabellid polychaetes; and a pelecypod mollusc (Fig. 8a) The solitary ascidian was the most extreme outlier with a somatic C:N ratio of 70. Macrofaunal phyto $\mathrm{C}_{\text {:phyto }} \mathrm{N}$ assimilation ratios were variable between taxa (Fig. 8b). However, most values ranged between 10 and 60 indicating preferential 


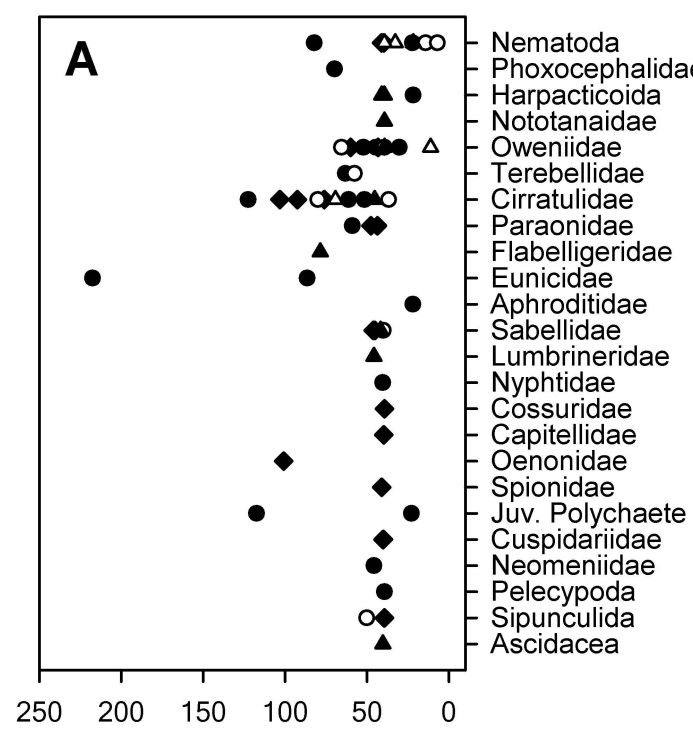

\section{Biomass Specific phyto $\mathrm{C}$ Uptake \\ $\left(\mu \mathrm{g} \mathrm{C} . \mathrm{mg}^{-1}\right)$}
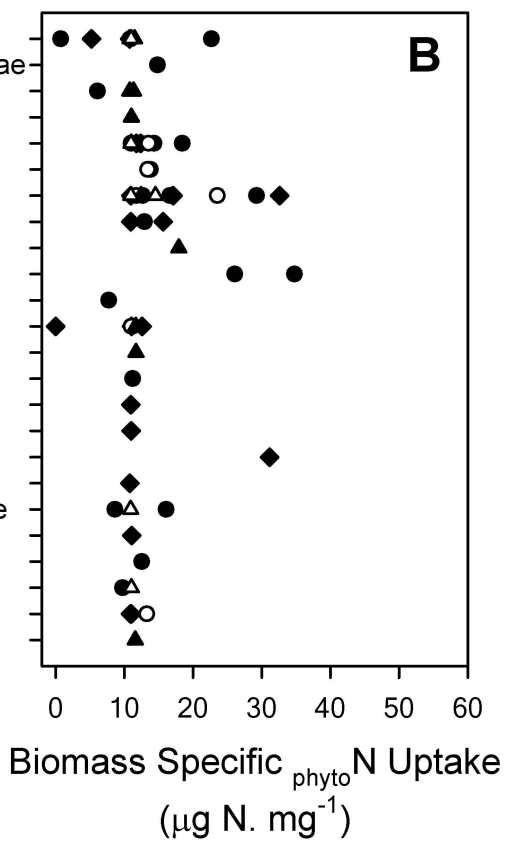

Fig. 6. Biomass specific assimilation of ${ }_{\text {phyto }} \mathrm{C}$ and ${ }_{\text {phyto }} \mathrm{N}$ by individual macrofaunal taxa at stations $\mathrm{T} 1800 \mathrm{~m}(4 \mathrm{day}, \diamond), \mathrm{T} 2800 \mathrm{~m}(4 \mathrm{day}$ $\bullet, 7$ day $\circ$ ) and T2 $1100 \mathrm{~m}$ (4 day $\boldsymbol{\Lambda}, 7$ day $\triangle$ ).

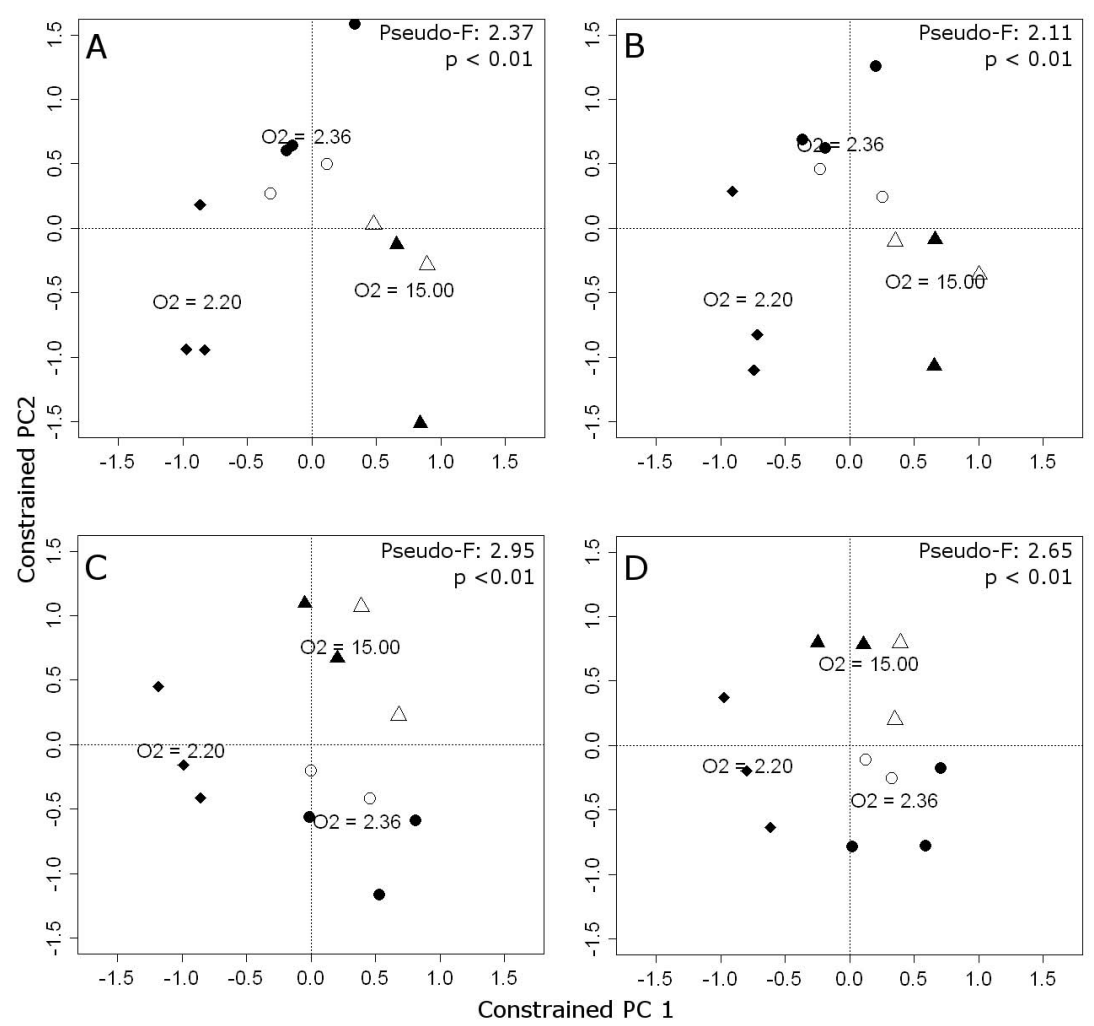

Fig. 7. Constrained ordinations models of macrofaunal assemblage structure, determined by (A) biomass $\mathrm{C}$ and (B) biomass $\mathrm{N}$, and the macrofaunal assimilation of (C) ${ }_{\text {phyto }} \mathrm{C}$ and (D) phyto $^{\mathrm{N}}$, at stations T1 $800 \mathrm{~m}$ (4 day, $\bullet$ ), T2 $800 \mathrm{~m}(4$ day $\bullet, 7$ day o) and T2 $1100 \mathrm{~m}(4$ day $\boldsymbol{\Delta}, 7$ day $\triangle)$. 
assimilation of phyto $\mathrm{C}$, relative to the $\mathrm{C}: \mathrm{N}$ ratio of the labelled phytodetritus (4.04). phyto $\mathrm{C}_{\text {phyto }} \mathrm{N}$ ratios between 100 and 250 suggest a strong carbon demand by the nematodes; eunicid, sabellid and spionid polychaetes; pelecypod molluscs; and the ascidian. Biomass specific phyto $\mathrm{C}:$ phyto $\mathrm{N}$ assimilation ratios exhibit considerably less variation, with most values ranging between 2 and 5 (Fig. 8c). These values are close to the $\mathrm{C}: \mathrm{N}$ ratio of the labelled phytodetritus, suggesting preferential assimilation of phyto $\mathrm{N}$, relative to the somatic $\mathrm{C}: \mathrm{N}$ ratio of each specimen.

\subsection{Discussion}

\subsubsection{Macrofaunal assemblage}

Changes in macrofaunal abundance and biomass were observed across the OMZ-impacted Indian margin. macrofauna were absent in the OMZ core (T1 $540 \mathrm{~m}$; $\left.\left[\mathrm{O}_{2}\right]=0.35 \mu \mathrm{mol}^{-1}\right)$, whilst in the lower OMZ boundary (800-1100 m), highest faunal density and biomass were found at $800 \mathrm{~m}$. Subsequently, both macrofauna abundance and biomass decreased between 800 and $1100 \mathrm{~m}$. Previous estimates of macrofaunal abundance and biomass at the western Indian continental margin are lower than those reported in the present study, with Ingole et al., (2010) reporting densities of 424 to $707 \mathrm{~m}^{-2}$, between 525 and $1524 \mathrm{~m}$. The present study is consistent with macrofaunal abundance estimates between 850 and $1100 \mathrm{~m}$ depth, at the OMZ-impacted Pakistan and Oman margins (Levin et al., 2000, 2009; Hughes et al., 2009). macrofaunal abundances were greater in the present study than those observed in non-impacted bathyal sediments, such as western Norwegian fjords (2930-4687 ind. $\mathrm{m}^{-2}$; Witte et al., 2003a; Sweetman and Witte, 2008a) and Faroe-Shetland Channel (5166 ind. $\mathrm{m}^{-2}$; Gontikaki et al., 2011). Comparison of biomass between studies is difficult because of the variations in sampling methodology and metric used (e.g. carbon content vs. dry weight). Nevertheless, our results indicate that macrofauna biomass is lower at the OMZ-impacted Indian margin than in non-impacted bathyal sediments, where biomass ranges between 200 and $1000 \mathrm{mg} \mathrm{C} \mathrm{m}^{-1}$ (Witte et al., 2003a; Sweetman and Witte 2008a; Gontikaki et al., 2011) Instead, macrofaunal assemblages at the Indian margin were comparable with the abyssal Arabian Sea (2800-2860 m $\mathrm{m}^{-2}, 9.2-171.6 \mathrm{mg} \mathrm{C} \mathrm{m}^{-2}$; Witte, 2000). Thus, the Indian margin macrofaunal assemblage is characterised by high densities of small organisms. This supports Levin's (2003) hypothesis that small-bodied organisms, whose bodies have a greater surface area for gas-exchange, are more prevalent under conditions of persistent dysoxia (low oxygen).

An oxygen threshold between 540 and $800 \mathrm{~m}$ $\left(\left[\mathrm{O}_{2}\right]=0.35-2.20 \mu \mathrm{moll}^{-1}\right)$ limited penetration of macrofauna into the OMZ core. This is consistent with observations made at the Pakistan margin, where macrofaunal presence and activity were limited by an oxygen threshold at $\sim 700 \mathrm{~m}$ depth (Levin et al., 2009; Woulds et al., 2007). For example on the Pakistan margin, the amphinomid Linopherus spp. dominated the macrofauna between 700 and $1100 \mathrm{~m}$ (Levin et al., 2009), and the spionid Prionospio spp. was observed in high densities in OMZ impacted regions of the Indian and Oman continental margin (Ingole et al., 2010; Levin et al., 2000). In the present study, macrofaunal assemblages were dominated by two polychaete families, the cirratulids (Cirratulus spp.; Tharyx spp. monticellina spp.) and the oweniids (Owenia spp.) between 800 and $1100 \mathrm{~m}$. This contrasts with Ingole et al. (2010) study at the Indian margin, highlighting the influence of spatial and temporal heterogeneity upon benthic macrofaunal assemblages. Within OMZs, zonation of the macrofaunal assemblages is associated with taxon-specific differences in tolerance to dysoxia, causing the abundance of annelids, molluscs, crustacea and echinoderms to increase sequentially (Levin et al., 2000; Levin et al., 2009). The spatial-scale of present study is too small to observe this zonation. However, family-level changes in macrofaunal distribution occured across the lower OMZ boundary exhibiting a significant relationship to differences in oxygen availability. Previously, changes in benthic macrofaunal assemblages have been linked to changes in both oxygen availability and sediment geochemistry, on OMZ-impacted margins (Levin and Gage, 1998; Levin et al., 2009). The present study could not isolate the effects of sediment geochemistry upon macrofaunal assemblage structure from the spatial heterogeneity at each station. Nevertheless, it is feasible that small-scale changes in sediment geochemical parameters, at each station, may be an important factor driving the spatial variability of the macrofaunal assemblages.

\subsubsection{Linking Assemblage structure to macrofaunal feeding responses}

Traditionally, the feeding ecology of deep-sea macrofauna has been investigated using specimen morphology and comparison with the feeding modes of shallow-water analogues (e.g. Jumars et al., 1990; Pagliosa, 2005). The use of both natural stable-isotopic signatures and stable isotope-labelling experiments provide powerful tools to test these assumptions and trace the flow of carbon and nitrogen through macrofaunal assemblages (Aberle and Witte 2003; Witte et al., 2003a; Sweetman and Witte 2008a, 2008b; Gontikaki et al., 2011). In the present study, the macrofaunal assemblages at both 800 and $1100 \mathrm{~m}$ were dominated by polychaetes, such as cirratulids and oweniids, defined as surface-deposit feeders by Fauchald and Jumars (1979). Natural stable-isotopic signatures of macrofauna at the Indian margin support this assumption, with faunal $\delta^{13} \mathrm{C}$ and $\delta^{15} \mathrm{~N}$ signatures (Fig. 4) similar to the natural $\delta^{13} \mathrm{C}$ and $\delta^{15} \mathrm{~N}$ values of sediment $\mathrm{OM}$ at each station (Fig. B1). Natural abundance $\delta^{13} \mathrm{C}$ values were similar to those of marine phytoplankton (Fry and Sherr 


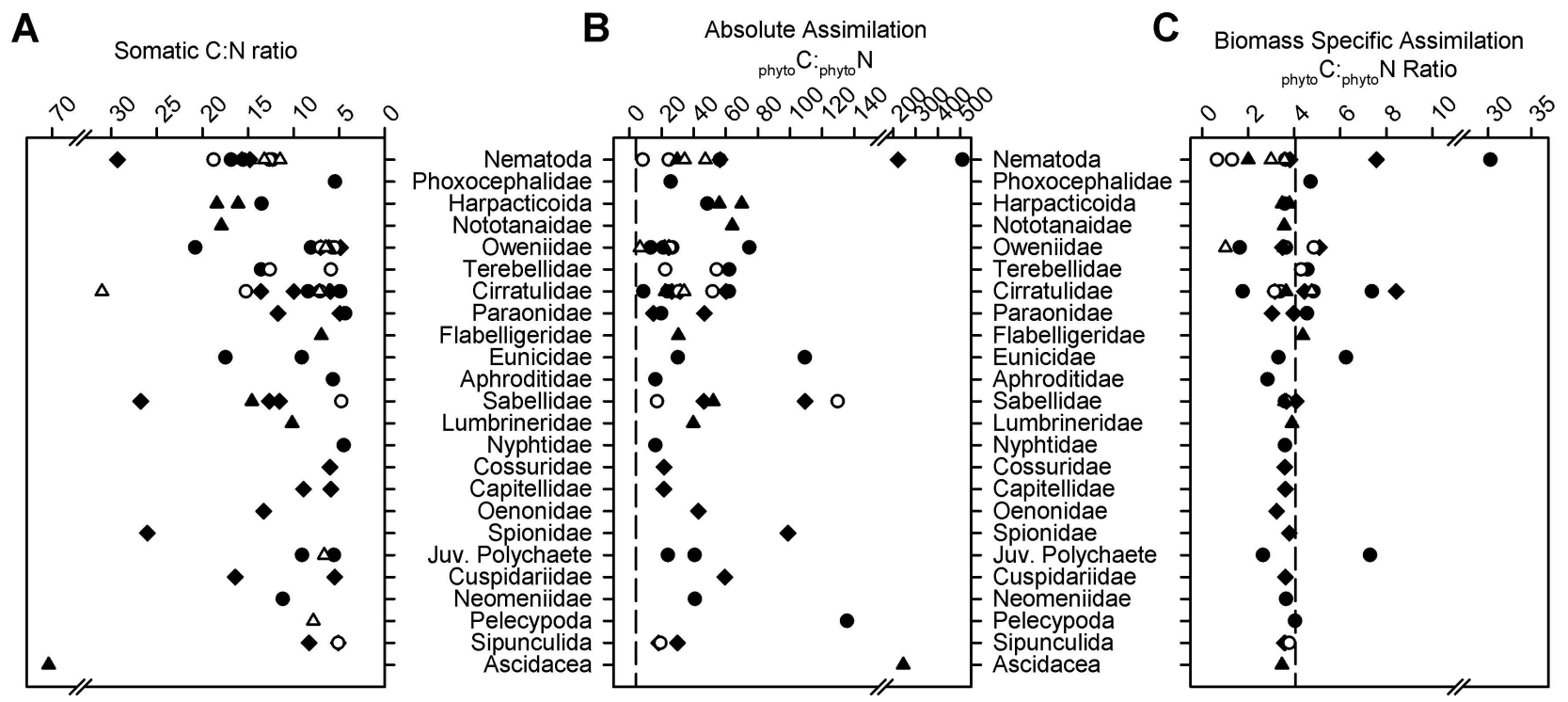

Fig. 8. C:N stoichiometry of the (A) somatic biomass (B) overall assimilation of phyto $\mathrm{C}$ and phyto $^{\mathrm{N}}$ and $(\mathbf{C})$ biomass specific assimilation of phyto $\mathrm{C}$ and ${ }_{\text {phyto }} \mathrm{N}$ of individual macrofaunal taxa at stations T1 $800 \mathrm{~m}$ (4 day, $\bullet$ ), T2 $800 \mathrm{~m}$ (4 day $\diamond, 7$ day $\bullet$ and T2 $1100 \mathrm{~m}(4 \mathrm{day} \boldsymbol{\Delta}, 7$ day $\triangle$ ). Dashed lines represent the phytodetrital C:N ratio as a reference.

1984) indicating the importance of phytodetritus as an OM source for these macrofauna. The natural $\delta^{15} \mathrm{~N}$ signatures of most macrofauna were relatively depleted compared to those found in oxygenated bathyal sediments (Sweetman and Witte 2008a; Gontikaki et al., 2011). This indicates that macrofauna at the Indian margin are reliant on small low-quality POM particles as a food source (e.g. Rau et al., 1990). Relatively high variability in the $\delta^{15} \mathrm{~N}$ signatures of the nephytid polychaetes and other groups may reflect variations in POM quality within the sediments, whilst heavier $\delta^{15} \mathrm{~N}$ signatures in the phoxocephalid crustaceans and goniadid polychaetes is indicative of omnivorous or predatory feeding modes (Vanderklift and Ponsard, 2003).

The present study compares macrofaunal feeding responses across the OMZ-impacted Indian margin, tracing the uptake of ${ }^{13} \mathrm{C}:{ }^{15} \mathrm{~N}$ labelled phytodetritus doses (650 $\mathrm{m} \mathrm{C} \mathrm{m}^{-2} ; 160 \mathrm{mg} \mathrm{N} \mathrm{m}^{-2}$ ) at four stations. Feeding responses were observed at the 800 and $1100 \mathrm{~m}$ stations, with phyto $\mathrm{C}$ and phyto $\mathrm{N}$ uptake highest at $800 \mathrm{~m}$, where macrofaunal biomass was greatest. Macrofaunal uptake decreased between four and seven days, similar to the trend observed by Witte et al., (2003b) at the Porcupine Abyssal Plain. However, in the present study decreases in assimilation of ${ }_{\text {phyto }} \mathrm{C}$ and ${ }_{\text {phyto }} \mathrm{N}$ may be primarily driven by differences in faunal biomass between experimental incubations. Macrofaunal feeding responses were strongly correlated with changes in macrofaunal assemblage structure, exhibiting significant relationships to station-specific oxygen concentrations between 800 and $1100 \mathrm{~m}$. Thus, oxygen availability may drive changes in macrofaunal assemblage structure that control
POC and PON processing across the lower OMZ boundary.

It is hypothesised that family-level differences in trophic ecology and individual variation in feeding behaviour influence the feeding responses of deep-sea macrofaunal assemblages (Witte et al., 2003a; Sweetman and Witte 2008a, b). In deep sea sediments, bulk OM uptake by the macrofauna is primarily driven by the feeding responses of the dominant taxonomic groups to POM sedimentation. In particular, deposit feeding polychaetes dominate macrofaunal uptake of POM at the bathyal continental margins (Sweetman and Witte, 2008a; Gontikaki et al., 2011,). In the present study phyto $\mathrm{C}$ and phyto $\mathrm{N}$ assimilation were dominated by cirratulid polychaetes at the $800 \mathrm{~m}$, whilst a solitary large ascidian dominated assimilation of ${ }_{\text {phyto }} \mathrm{C}$ in one experiment at $1100 \mathrm{~m}$. This is consistent with observations that consumption of POM is proportional to consumer biomass (e.g. Middelburg et al., 2000; Woulds et al., 2007).

The present study demonstrates that within OMZimpacted sediments, changes in macrofaunal assemblage structure influence seafloor OM recycling. This confirms the hypothesis that variations in macrofaunal organic matter processing are driven by macrofaunal assemblage structure (Witte et al., 2003a; Sweetman and Witte, 2008a). In the present study, most macrofaunal taxa exhibited relatively constant biomass specific assimilation of phyto $\mathrm{C}$ and phyto $\mathrm{N}$, with the exception of cirratulid, eunicid and flabelligerid polychaetes. These taxa are characterised by Fauchald and Jumars (1979) as motile surface-deposit feeders, suggesting they can make at least limited self-directed movements to exploit patchy food resources. This may facilitate 
higher biomass-specific phyto $\mathrm{C}$ and phyto $\mathrm{N}$ assimilation and, as a result, the numerically abundant cirratulids dominated assemblage-level POC and PON processing. These cirratulids fulfilled an ecological role at the Indian margin that was similar to that of the highly active amphinomid Linopherus spp. on the OMZ-impacted Pakistan margin (Woulds et al., 2007). Direct comparison between the present study and previous research is challenging because of differences in sample size, incubation time and phytodetrital dose added. However, the biomass-specific phyto $\mathrm{C}$ assimilation values indicate that feeding activity by the macrofaunal assemblages is higher on the OMZ-impacted Indian margin compared with oxygenated bathyal (Witte et al., 2003a; Sweetman and Witte, 2008a; Gontikaki et al., 2011) and abyssal (Aberle and Witte, 2003; Sweetman and Witte, 2008b) sediments. Therefore, our results support the hypothesis that OMZ boundary sediments are sites of enhanced macrofaunal activity (Woulds et al., 2009).

\subsection{3 $\mathrm{C}$ : $\mathrm{N}$ coupling of macrofaunal feeding responses}

In deep-sea sediments faunal feeding responses are calibrated by the quantity and relative quality of organic matter supplied (Aspetsberger et al., 2007; Buhring et al., 2006). However, the mechanisms driving these responses are poorly studied. The availability of organic matter for biological utilisation (lability) is strongly correlated to its relative organic nitrogen content (Cowie et al., 1999; Hedges and Keil, 1995). The relationship between carbon and nitrogen assimilation provides a useful framework to explore how organismal feeding ecology influences ecosystem-scale carbon and nitrogen cycling (following Sterner and Elser 2002).

The present study is the first to simultaneously trace the uptake of POC and PON by deep-sea macrofaunal assemblages. Previously, dual-labelling $\left({ }^{13} \mathrm{C}:{ }^{15} \mathrm{~N}\right)$ experiments have demonstrated the importance of faunal C:N coupling in coastal and estuarine sediments. Evrard et al., (2010) indicated a strong preference for nitrogen in "meio-" faunal organisms $(63-1000 \mu \mathrm{m})$ following organic matter deposition in a coastal sublittoral sediment, a size fraction which encompasses the common definition of deep-sea macrofauna $(>250 \mu \mathrm{m})$. Likewise, Rossi et al., (2007) demonstrated organic nitrogen to have reduced residence time within estuarine sediments compared with organic $\mathrm{C}$, with macrofauna preferentially consuming $25 \%$ of the ${ }^{15} \mathrm{~N}$ label from a phytodetrital source versus just $3 \%$ of the ${ }^{13} \mathrm{C}$ label. This contrasts with the present study, where macrofaunal assimilation of ${ }_{\text {phyto }} \mathrm{C}$ and ${ }_{\text {phyto }} \mathrm{N}$ accounted for $\sim 1 \%$ and $\sim 0.4 \%$ respectively of the phytodetrital dose. These results indicate that overall faunal $\mathrm{C}: \mathrm{N}$ coupling was driven by preferential assimilation of ${ }_{\text {phyto }} \mathrm{C}$ at the assemblage level. This is a surprising observation, given that nitrogen is a limiting nutrient in marine sediments.
The mechanisms that drive faunal uptake of POM act at the organismal level, balancing demands for organic carbon (as an energy source) and nitrogen (for somatic growth and reproduction) against the need to detoxify and excrete nitrogenous waste products (Raubenheimer and Simpson, 2004). In the present study, family-level C:N coupling indicated preferential uptake of ${ }_{\text {phyto }} \mathrm{C}$ by the fauna (Fig. 8a). The somatic tissues of both marine and freshwater benthic invertebrates are protein-rich, with $\mathrm{C}: \mathrm{N}$ ratios ranging between 1.5 and 9 ( e.g. Liess and Hillebrand, 2005; Clarke 2008). However, At the Indian margin macrofaunal C:N ratios exhibited greater variability, ranging between 5 and 20. Whilst the presence of skeletal material (e.g. carbonate) can result in high C:N ratios, all specimens were washed in ultra-pure water and de-carbonated prior to analysis. The highest somatic C:N ratio was recorded in the solitary ascidian as a consequence of its tunicin (carbohydrate) test (Goodbody 1974). Thus, availability of organic carbon is likely to represent an important limiting nutrient for this organism. Overall, higher somatic C:N ratios may indicate accumulation of lactate within faunal tissues. Lactate is an end product of anaerobic metabolism whose accumulation in animal tissue indicates persistent oxygen-stress (Seibel, 2011). Subsequently, we hypothesise that modest energy yield from anaerobic metabolism increases faunal demand for organic $\mathrm{C}$, but limits its mineralisation to dissolved inorganic carbon, resulting in the observed preferential assimilation of ${ }_{\text {phyto }} \mathrm{C}$.

Animals are characterised by stoichiometric homeostasis, adapting their feeding responses to maintain nutrient consumption at an optimum level (Frost et al., 2002, 2005). The phyto $\mathrm{C}$ : phyto $\mathrm{N}$ ratio for biomass-specific uptake (Fig. 8c) supports the proposed hypothesis. These data show relationships between phyto $\mathrm{C}$ and phyto $\mathrm{N}$ assimilation were similar across the major taxa, driven by a strong $\mathrm{N}$ preference. This indicates that macrofaunal feeding maximises organic $\mathrm{N}$ uptake relative to an internal nutrient budget, approximated by individual somatic C:N ratios. Macrofauna contribute to $\mathrm{OM}$ remineralisation through respiration (DIC) and ammonification (DIN), and so assimilation of phyto $\mathrm{C}$ and phyto $\mathrm{N}$ into their tissues accounts for only a fraction of their activity. In marine sediments macrofaunal are ammonotelic, mineralising organic $\mathrm{N}$ directly to ammonia which is rapidly excreted (Wright 1995). Therefore, much of the phyto $\mathrm{N}$ processed by fauna is excreted, whilst the low-oxygen conditions resulted in phyto $\mathrm{C}$ accumulation within tissues. In a complimentary study, Hunter et al., (2012) observed microbial activity was limited by the presence of fauna across the Indian margin OMZ. Although faunal assimilation of phyto $\mathrm{C}$ and ${ }_{\text {phyto }} \mathrm{N}$ were relatively small, they were concomitant with losses of labile $\mathrm{OM}$ and ${ }_{\text {phyto }} \mathrm{N}$ from the sediments. This indicates that faunal activity is an important control upon $\mathrm{C}$ and $\mathrm{N}$ cycling in low-oxygen sediments. 


\section{Conclusions}

Within the lower boundary of the Indian margin OMZ, changes in oxygen availability influence the composition of the macrofaunal assemblages. Differences in short term POC and PON processing were strongly correlated to oxygendriven changes in macrofaunal assemblage structure. At present there is a lack of data on macrofaunal feeding behaviour, with much emphasis placed upon the role of broad functional groups (e.g. Fauchald and Jumars, 1979; Pagliosa, 2005). The present study is the first to use stoichiometric ratios of $\mathrm{C}$ and $\mathrm{N}$ to investigate macrofaunal feeding responses, identifying the importance of individual nutrient budgets as drivers of the macrofaunal pathways for organic matter recycling.

\section{Appendix A}

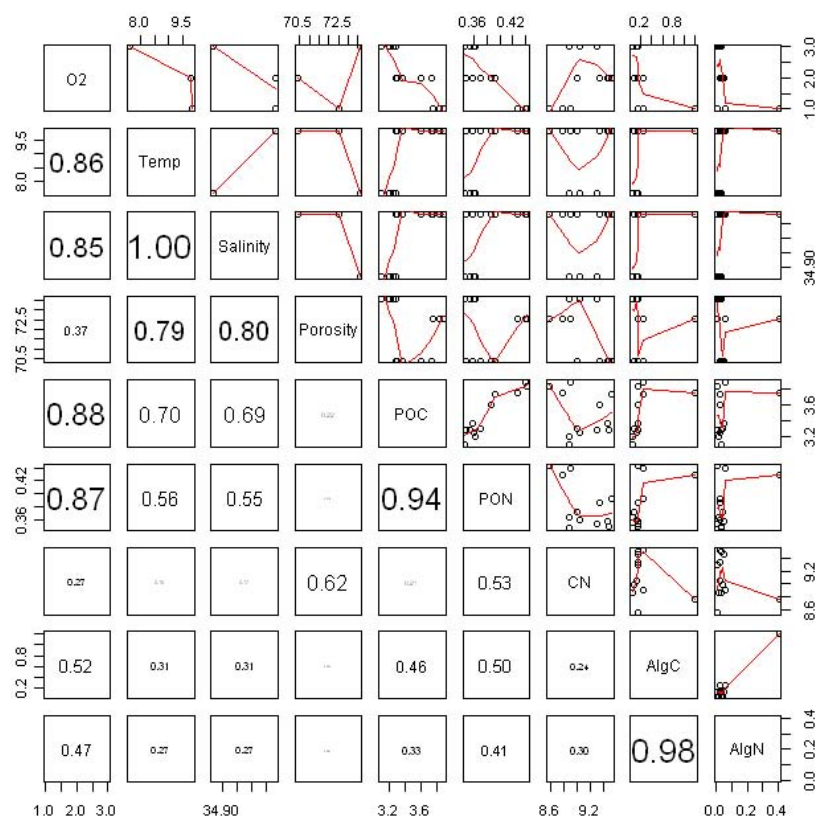

Fig. A1. Paired Scatterplots of Environmental Data, showing the level of correlation between variables as the Spearman's rank correlation coefficient.

\section{Appendix B}

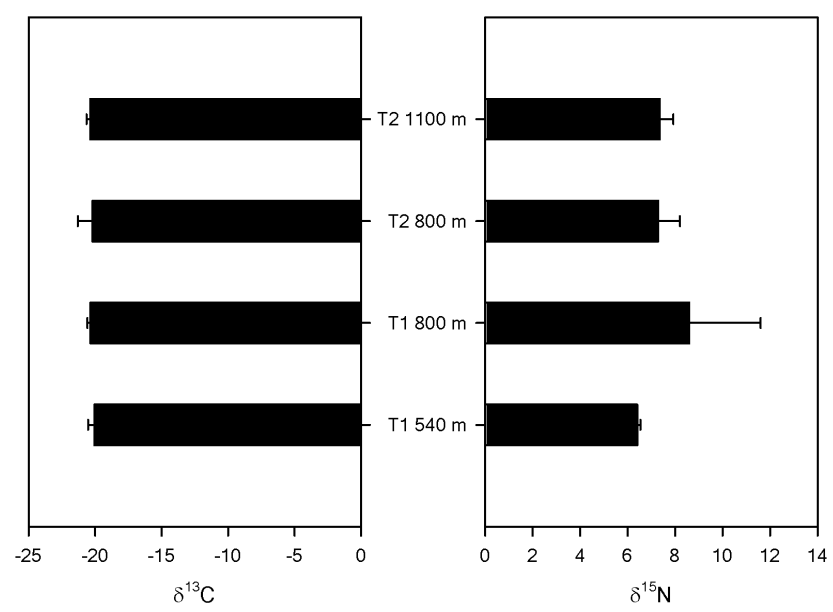

Fig. B1. Mean ( \pm standard deviation) natural stable-isotope signatures of sediment organic matter $(00-05 \mathrm{~cm})$ at the four experimental stations. Data is derived from 3 push cores taken at each station.

\section{Supplementary material related to this article is available online at: http://www.biogeosciences. net/9/993/2012/bg-9-993-2012-supplement.pdf.}

Acknowledgements. The authors gratefully acknowledge the help and support of the officers and crew of the R/V Yokosuka and Shinkai 6500; and the scientific team during cruise YK08-11. Without their efforts this work could not have been completed. We acknowledge the assistance of Waji Naqvi (NIO, India); Hidetaka Nomaki (JAMSTEC, Japan) and Markus Moeseneder (NOCS, UK), coordinating shipment of samples and equipment. We thank Val Johnson (U. Aberdeen, UK) for her assistance with algal culture and pre- and post- cruise logistics; and Juliet Thornton (U. Aberdeen, UK) for her assistance with macrofaunal sorting and identification. Mass spectroscopy was conducted at the UC Davis Stable Isotope Facility under the management of David Harris. The work was supported by the Carnegie Trust (United Kingdom) (grant no. ERI 008427 to U Witte). WRH was supported by a NERC Doctoral Training Grant (NE/G523904/1). LAL thanks co-author H. Kitazato and JAMSTEC for facilitating her participation.

Edited by: C. P. Slomp 


\section{References}

Aberle, N. and Witte, U.: Deep-sea macrofauna exposed to a simulated sedimentation event in the abyssal NE Atlantic: in situ pulse-chase experiments using ${ }^{13} \mathrm{C}$-labelled phytodetritus, Mar. Ecol. Prog. Ser., 251, 37-47, 2003.

Aller, R. C.: Bioturbation and remineralization of sedimentary organic matter: effects of redox oscillation, Chem. Geol., 114, 331-345, 1994.

Anderson, M. J.: Distance-based tests for homogeneity of multivariate dispersions, Biometrics, 62, 245-253, 2006.

Anderson, M. J. and Willis, T. J.: Canonical analysis of principal coordinates: a useful method of constrained ordination for ecology, Ecol., 84, 511-525, 2003.

Aspetsberger, F., Zabel, M., Ferdelman, T., Struck, U., Mackensen, A., Ahke, A., and Witte, U.: Instantaneous benthic response to different organic matter quality: in situ experiments in the Benguela Upwelling System, Mar. Biol. Res., 3, 342-356, 2007.

Bakun, A. and Weeks, S. J.: Greenhouse gas buildup, sardines, submarine eruptions and the possibility of abrupt degradation of intense marine upwelling ecosystems, Ecol. Lett., 7, 1015-1023, 2004.

Bedrick, E. J. and Tsai, C. L.: Model selection for multivariate regression in small samples, Biometrics, 50, 226-231, 1994.

Buhring, S. I., Lampadariou, N., Moodley, L., Tselepides, A., and Witte, U.: Benthic microbial and whole-community responses to different amounts of ${ }^{13} \mathrm{C}$-enriched algae: in situ experiments in the deep Cretan Sea (Eastern Mediterranean), Limnol. Oceanogr, 51, 157-165, 2006.

Clarke, A.: Ecological stoichiometry in six species of Antarctic marine benthos, Mar. Ecol. Prog. Ser., 369, 25-37, 2008.

Cowie, G. L., Calvert, S. E., Pedersen, T. F., Schulz, H., and Von Rad, U.: Organic content and preservational controls in surficial shelf and slope sediments from the Arabian Sea (Pakistan Margin), Mar. Geol., 161, 23-38, 1999.

Devol, A. H. and Hartnett, H. E.: Role of the oxygen-deficient zone in transfer of organic carbon to the deep ocean, Limnol. Oceanogr., 46, 1684-1690, 2001.

Evrard, V., Soetaert, K., Heip, C. H. R., Huettel, M., Xenopoulos, M. A., and Middelburg, J. J.: Carbon and nitrogen flows through the benthic food web of a photic subtidal sandy sediment, Mar. Ecol. Prog. Ser., 416, 1-16, 2010.

Fauchald, K. and Jumars, P. A.: The Diet of Worms: a study of polychaete feeding guilds, Oceanogr. Mar. Biol. Ann. Rev., 17, 193-284, 1979.

Frost, P. C., Stelzer, R. S., Lamberti, G. A., and Elser, J. J.: Ecological stoichiometry of trophic interactions in the benthos: understanding the role of C:N:P ratios in lentic and lotic habitats, J. N. Am. Benthol. Soc., 21, 515-528, 2002.

Frost, P. C., Evans-White, M. A., Finkel, Z. V., Jensen, T. C. and Matzek, V.: Are you what you eat? Physiological constraints on organismal stoichiometry in an elementally imbalanced world, Oikos., 109, 18-28, 2005.

Fry, B. and Sherr, E. B.: $\delta 13 \mathrm{C}$ measurements as indicators of carbon flow in marine and freshwater ecosystems, Contrib. Mar. Sci., 27, 13-47, 1984.

Giblin, A. E., Foreman, K. H., and Banta, G. T.: Biogeochemical processes and marine betnhic community structure: which follows which?, in: Linking Species and Ecosystems, edited by: Jones, G. C. and Adams, E., Chapman and Hall, New York,
USA., 29-36, 1995.

Gontikaki, E., Mayor, D. J., Narayanaswamy, B. E., and Witte, U.: Feeding strategies of deep-sea sub-Arctic macrofauna of the Faroe-Shetland Channel: Combining natural stable isotopes and enrichment techniques, Deep-Sea Res. Pt. I, 58, 160-172, 2011.

Goodbody, I.: The physiology of ascidians, Adv. Mar. Biol., 2, 1149, 1974.

Hartnett, H. E., Keil, R. G., Hedges, J. I., and Devol, A. H.: Influence of oxygen exposure time on organic carbon preservation in continental margin sediments, Nature, 391, 572-574, 1998.

Hedges, J. I. and Keil, R. G.: Sedimentary organic matter preservation: an assessment and speculative synthesis, Mar. Chem., 49, 81-115, 1995.

Helly, J. J. and Levin, L. A.: Global distribution of naturally occurring marine hypoxia on continental margins, Deep-Sea Res. Pt. I, 51, 1159-1168, 2004.

Hughes, D. J., Lamont, P. A., Levin, L. A., Packer, M., Feeley, K., and Gage, J. D.: Macrofaunal communities and sediment structure across the Pakistan margin Oxygen minimum Zone, NorthEast Arabian Sea, Deep-Sea Res. Pt. II, 56, 434-448, 2009.

Hunter, W. R., Oguri, K., Kitazato, H., Ansari, Z. A., and Witte, U.: Epi-benthic megafaunal zonation across an oxygen minimum zone at the Indian continental margin, Deep-Sea Res. Pt. I, 58, 699-710, 2011.

Hunter, W. R., Veuger, B., and Witte, U.: Carbon and nitrogen incorporation by heterotrophic bacteria in low oxygen environments is regulated by faunal competition and resulting labile organic matter loss, ISME Journal, in review, ISMEJ-1100860OAR, 2012.

Ingole, B. S., Sautya, S., Sivadas, S., Singh, R., and Nanajkar, M.: Macrofaunal community structure in the western Indian continental margin including the oxygen minimum zone, Mar. Ecol., 31, 148-166, 2010.

Jackson, D. A.: PROTEST: A PROcrustean Randomization TEST of community environment concordance, Ecosci., 2, 297-303, 1995.

Jumars, P. A., Mayer, L. M., Deming, J. W., Baross, J. A., and Wheatcroft, R. A.: Deep-Sea Deposit-Feeding Strategies Suggested by Environmental and Feeding Constraints, Phil. Trans. Roy. Soc. A., 331, 85-101, 1990.

Kristensen, E. and Holmer, M.: Decomposition of plant materials in marine sediment exposed to different electron acceptors $\left(\mathrm{O}_{2}\right.$, $\mathrm{NO}_{3}^{-}$, and $\mathrm{SO}_{4}^{-2}$ ) with emphasis on substrate origin, degradation kinetics, and the role of bioturbation, Geochim. Cosmochim. Acta, 65, 1404-1419, 2001.

Levin, L. A.: Oxygen minimum zone benthos: Adaptation and community response to hypoxia, Oceanogr. Mar. Biol. Ann. Rev., 41, $1-45,2003$.

Levin, L. A. and Edesa, S.: The ecology of cirratulid mudballs on the Oman margin, northwest Arabian Sea, Mar. Biol., 128, 671678, 1997.

Levin, L. A. and Gage, J. D.: Relationships between oxygen, organic matter and the diversity of bathyal macrofauna, Deep-Sea Res. Pt. II, 45, 129-163, 1998.

Levin, L. A., Huggett, C. L., and Wishner, K. F.: Control of deepsea benthic community structure by oxygen and organic-matter gradients in the eastern Pacific Ocean, J. Mar. Res., 49, 763-800, 1991.

Levin, L., Blair, N., DeMaster, D., Plaia, G., Fornes, W., Martin, 
C., and Thomas, C.: Rapid subduction of organic matter by maldanid polychaetes on the North Carolina slope, J. Mar. Res., 55, 595-611, 1997.

Levin, L. A., Blair, N. E., Martin, C. M., DeMaster, D. J., Plaia, G., and Thomas, C. J.: Macrofaunal processing of phytodetritus at two sites on the North Carolina margin: in situ experiments using ${ }^{13}$ C-labeled diatoms, Mar. Ecol. Prog. Ser., 182, 37-54, 1999.

Levin, L. A., Gage, J. D., Martin, C., and Lamont, P. A.: Macrobenthic community structure within and beneath the oxygen minimum zone, NW Arabian Sea, Deep-Sea Res. Pt. II, 47, 189226, 2000.

Levin, L. A., Whitcraft, C. R., Mendoza, G. F., Gonzalez, J. P., and Cowie, G.: Oxygen and organic matter thresholds for benthic faunal activity on the Pakistan margin oxygen minimum zone (700-1100 m), Deep-Sea Res. Pt. II, 56, 449-471, 2009.

Liess, A. and Hillebrand, H.: Stoichiometric variation in C:N, C:P, and N:P ratios of littoral benthic invertebrates, J. N. Am. Benthol. Soc., 24, 256-269, 2005.

Middelburg, J. J., Soetaert, K., and Herman, P. M. J.: Empirical relationships for use in global diagenetic models, Deep-Sea Res. Pt. I, 44, 327-344, 1997.

Middelburg, J. J., Barranguet, C., Boschker, H. T. S., Herman, P. M. J., Moens, T., and Heip, C. H. R.: The fate of intertidal microphytobenthos carbon: An in situ ${ }^{13} \mathrm{C}$ labelling study, Limnol. Oceanogr., 45, 1224-1234, 2000.

Moodley, L., Middelburg, J. J., Soetaert, K., Boschker, H. T. S., Herman, P. M. J., and Heip, C. H. R.: Similar rapid response to phytodetritus deposition in shallow and deep-sea sediments, J. Mar. Res., 63, 457-469, 2005.

Oksanen, J., Kindt, R., Legendre, P., O’Hara, B., Simpson, G. L., Solymos, P. M., Stevens, H. H., and Wagner, H.: vegan: Community Ecology Package, 1.15-4, 2009.

Pagliosa, P. R.: Another diet of worms: The applicability of polychaete feeding guilds as a useful conceptual framework and biological variable, Mar. Ecol., 26, 246-254, 2005.

Persson, J., Fink, P., Goto, A., Hood, J. M., Jonas, J., and Kato, S.: To be or not to be what you eat: Regulation of stoichiometric homeostasis among autotrophs and heterotrophs, Oikos, 119, 741-751, 2010.

R Development Core Team: R: A language and environment for statistical computing, R Foundation for Statistical Computing, 2009.

Rau, G. H., Teyssie, J. L., Rassoulzadegan, F., and Fowler, S. W.: ${ }^{13} \mathrm{C} /{ }^{12} \mathrm{C}$ and ${ }^{15} \mathrm{~N} /{ }^{14} \mathrm{~N}$ among size-fractionated marine particles: implications for their origin and trophic relationships, Mar. Ecol. Prog. Ser., 59, 33-38, 1990.

Raubenheimer, D. and Simpson, S. J.: Organismal stoichiometry: Quantifying non-independence among food components, Ecol, 85, 1203-1216, 2004.

Riedel, B., Zuschin, M., Haselmair, A., and Stachowitsch, M.: Oxygen depletion under glass: Behavioural responses of benthic macrofauna to induced anoxia in the Northern Adriatic, J. Exp. Mar. Biol. Ecol., 367, 17-27, 2008.

Rossi, F.: Recycle of buried macroalgal detritus in sediments: Use of dual-labelling experiments in the field, Mar. Biol., 150, 10731081, 2007.
Seibel, B. A.: Critical oxygen levels and metabolic suppression in oceanic oxygen minimum zones, J. Exp. Biol., 21, 326-336, 2011.

Smith Jr., K. L., Ruhl, H. A., Bett, B. J., Billett, D. S. M., Lampitt, R. S., and Kaufmann, R. S.: Climate, carbon cycling, and deepocean ecosystems, Proc. Natl. Acad. Sci., 106, 19211-19218, 2010.

Sterner, R. W. and Elser, J. J.: Ecological Stoichiometry: The biology of elements from molecules to the biosphere, Princeton University Press, Princeton, USA, 2002.

Stramma, L., Johnson, G. C., Sprintall, J., and Mohrholz, V.: Expanding oxygen-minimum zones in the tropical oceans, Science, 320, 655-658, 2008.

Sweetman, A. and Witte, U.: Macrofaunal response to phytodetritus in a bathyal Norwegian fjord, Deep-Sea Res. Pt. I, 55, 15031514, 2008a.

Sweetman, A. K. and Witte, U.: Response of an abyssal macrofaunal community to a phytodetrital pulse, Mar. Ecol. Prog. Ser., 355, 73-84, 2008b.

Vanderklift, M. A. and Ponsard, S.: Sources of variation in consumer-diet $\delta^{15} \mathrm{~N}$ enrichment: a meta-analysis, Oecologia, 136, 169-182, 2003.

Venables, W. N. and Ripley, B. D.: Modern Applied Statistics with S, Springer, New York, 2002.

Vitousek, P. M. and Howarth, R. W.: Nitrogen limitation on land and in the sea: how can it occur?, Biogeochem., 13, 87-115, 1991.

Wieltschnig, C., Fischer, U. R., Velimirov, B., and Kirschner, A. K. T.: Effects of deposit-feeding macrofauna on benthic bacteria, viruses and protozoan in a silty freshwater sediment, Microb. Ecol., 56, 1-12, 2008.

Witte, U.: Vertical distribution of metazoan macrofauna within the sediment at four sites with contrasting food supply in the deep Arabian Sea, Deep-Sea Res. Pt. II., 47, 2979-2997, 2000.

Witte, U., Aberle, N., Sand, M., and Wenzhofer, F.: Rapid response of a deep-sea benthic community to POM enrichment: an in situ experimental study, Mar. Ecol. Prog. Ser., 251, 27-36, 2003 a.

Witte, U., Wenzhofer, F., Sommer, S., Boetius, A., Heinz, P., Aberle, N., Sand, M., Cremer, A., Abraham, W. R., Jorgensen, B. B., and Pfannkuche, O.: In situ experimental evidence of the fate of a phytodetritus pulse at the abyssal sea floor, Nature, 424, 763-766, 2003b.

Woulds, C., Cowie, G. L., Levin, L. A., Andersson, J. H., Middelburg, J. J., Vandewiele, S., Lamont, P. A., Larkin, K. E., Gooday, A. J., Schumacher, S., Whitcraft, C., Jeffreys, R. M., and Schwartz, M.: Oxygen as a control on seafloor biological communities and their roles in sedimentary carbon cycling, Limnol. Oceanogr., 52, 1698-1709, 2007.

Woulds, C., Andersson, J. H., Cowie, G. L., Middelburg, J. J., and Levin, L. A.: The short-term fate of organic carbon in marine sediments: Comparing the Pakistan margin to other regions, Deep-Sea Res. Pt. II, 56, 393-402, 2009.

Wright, P. A.: Nitrogen excretion: three end products, many physiological roles., J. Exp. Biol., 198, 273-281, 1995. 